\title{
Drama Excerpt: Tool in Enhancing Speaking Ability for Junior High School
}

\author{
Otan Hidayat ${ }^{1}$, Sigit Apriyanto ${ }^{2}$ \\ ${ }^{1}$ Postgraduate Program, University of Ahmad Dahlan, otanhidayat@gmail.com \\ ${ }^{2}$ Applied Science and Technology, Universiti Tun Hussein Onn Malaysia, sigitteduh89@gmail.com
}

\begin{abstract}
ABSTRAK
Keyword:

Speaking ability,

Drama,

Communication,

Learning strategies.

The study aims to analyze drama excerpts as a tool in teaching speaking for Junior High School at the University of Saint Anthony. It also aims to determine the following: 1 . Speaking ability, of the students before exposure on drama excerpt 2 . The speaking ability after exposure on drama excerpt 3. The observed improvement among students along with body language, eye contact, introduction and closure, pacing, poise, and voice. 4 . Develop Oral communication guide for effective speaking material based on the findings of the study. A descriptive survey is used as a method of this study. The study population consisted of 10 students from 7 th-grade students at Saint Anthony University in the Philippines. Based from the findings of the study, found that the respondents were able to perform the conversation in the drama excerpt (because English is the medium of instruction in the Philippines, the result is higher, due to the interventions of a treatment given by the subject teacher on the correct and proper way of delivery and dialogue on drama excerpt, and there is a significant improvement observed to the students after the exposure to drama excerpt.
\end{abstract}

\section{Article History:}

Received: $13-10-2019$

Revised : 20-11-2019

Accepted: 26-12-2019

Online : 30-12-2019

\section{A. INTRODUCTION}

The dynamics of the life of the global community that started from the presence of free trade, the increasing number of foreign companies in Indonesia led to the use of International communication like English has become widespread and with the demands of the $21^{\text {st }}$ century, it becomes a must to master English to cope with this globalized era (for education, tourism, economic, etc. (Ariyanti, 2016). Thus, the need for innovation in English Language Teaching (ELT).

Mastery of speaking skills in English is a priority for many second or foreign language students (Widiati \& Cahyono, 2006). As a result, students often evaluate their success in learning languages and the effectiveness of their English language courses based on how well they feel they have improved in their spoken language skills. In other words, speaking is the only noticeable proficiency that someone will be evaluated in real-life communication (Nugroho, 2018). What the students need in a target language is the skill to use the language in acts of communication, because speaking is a very complex and different skill to learn especially by 


\section{2 | IJECA (International Journal of Education and Curriculum Application)}

Vol. 2, No. 3, December 2019, 1-9

foreign language students(Spielmann \& Radnofsky, 2001). In other words, learning to speak a foreign language will be facilitated when students are active to communicate because there is a proverb that says that we learn to read by reading and we learn to speak by speaking(Natarova, 2011; Umar, 2018). Speaking is a language skill or means of communication in which one can express his/her idea, feeling and information to others orally(Apriyanto \& Anum, 2018). Speaking skill needs direct interactions, in which someone speaks to someone directly.

The way someone speaks can create judgment and impression toward his/her speaking ability that might lead to the judgment of someone's overall performance. Oral skills are rarely ignored in EFL/ESL courses (witnessing the many conversations and other talking course books on the market) although the best way to approach teaching oral skills has long been the focus of methodological debates (Febriyanti, 2011). Teachers and textbooks use a variety of approaches, ranging from direct approaches that focus on specific features of oral interactions. (e.g. taking turns, topic management, questioning strategies) to indirect approaches that create conditions for oral interactions through group work, work assignments and other strategies (Radic-Bojanic \& Topalov, 2016).

In the Philippine Educational System, students who graduate from the primary level automatically enroll in junior high school, which covers four years from grades 7 to 10. This level is now mandatory and free for all students attending public schools. There are two main types of secondary schools: public high schools, which register more than 90 percent of all junior high school students, and vocational high schools. Besides, some private secondary schools have competitive entry requirements based on the entrance examination. Enter science schools, art schools, and schools with special curricular programs also with competitive exams sometimes including interviews, and auditions.

In contrast to the Philippines, in Indonesia, the implementation of English lectures that are already underway still emphasizes the ability of English in general rather than English for Specific Purposes. The available English lectures are relatively the same as the English material in other majors. Besides, the English material provided is Passive English rather than Active English so this is still not under Learner's Needs. English learning should include English knowledge and skills to support students' ability to teach in the classroom.

By this explanation, it is necessary to make changes from the General English into English for Specific Purposes. Besides, it is also necessary to make changes to lecture strategies that are Passive English to Active English through drama strategies or techniques as one solution that can answer the above problems. Furthermore, Theory on Dramatization by Janudom \& Wasanasomsithi (2009) state that drama is a powerful tool to develop self-confidence in children: "Many students thought that learning through the integration of these two techniques made the lessons more interesting and more enjoyable, as one of the students stated: "This class is different from other classes. It is moreinteresting" and another added, "It seems everyone enjoys learning, andthat makes me enjoy it, too." Furthermore, students commented that learning through these techniques made them feel more confident to apply their language skills, especially to express themselves."

Talking through drama learning will be more effective than speaking language skills can express ideas to be able to communicate especially through drama(Barbee, 2010). Drama is suitable for different student learning styles. Dramatization is attractive to all types of students. We receive and process information in different ways; the main thing is through our vision, hearing, and physical body. One of these channels tends to be dominant in each of us. When students dramatize, they use all the channels, and each student will draw on the most suitable 
for him. This means that all students in the class will be actively involved in activities, and language will "enter" through the channels that are most suitable for each of them, therefore learning to exist when they are doing or performing.The theory of speaking and dramatization is interrelated with the researcher's theory learning by Doing simply because performing drama excerpt through speaking by a group of students is already evidence of learning by Doing.

The reason the researchers took this title is that drama can be effective in developing English language skills spoken by students who speak English (Nihal, 2010). Drama can increase student motivation in learning English, reduce anxiety and improve mastery of English, especially speaking (Sapuan et al., 2012). Through drama, students can gain greater experience in using English. Furthermore, for Drama students who work in groups, they work as a team that must help each of the others. Some students are smarter than others. While some are more talented in learning English, some students are friendly, communicative, extroverted, while others are embarrassed, with introverts who are interested. In drama, everything that can be found and socialized by students of this type. Counterbalances the strength of each other and the lack of learners of English. Hopefully, we can build students' confidence because they do not work alone. Then, in the drama, each student gets the role to speak. The teacher will provide the manuscript and give students some exercises at home, so students are expected to speak English.

\section{B. METHODS}

The researcher utilized the descriptive qualitative method. According to Hancock, qualitative research is concerned with developing explanations of social phenomena. (Elliott \& Timulak, 2015). It aims to help the researcher to understand the social world and why things are the way they are. Hancock believes that it is concerned with the social aspects of the world and seeks to answer questions about 1) Why people behave the way they do, 2) How opinions and attitudes are formed. 3) How people are affected by the events that go on around them. 4) How and why cultures and practices have developed in the way they have.

The study used a descriptive survey method. A descriptive survey is any studies that gathered data on the characteristics and views of informants about the nature of language learning through the use of oral interviews or written questionnaires (Silverman, 2013). Miles, Huberman, \& Saldana (2014) added that the term "surveys" more narrowly as written questionnaires. He does so for two reasons. First, surveys are often thought of as exclusively written questionnaires, and secondly, the design and data analysis of interviews are generally quite different from surveys. The research will be used the first surveys as exclusively written questionnaires.

\section{Subject}

The subjects of this study are the grade 7 students at the University of Saint Anthony in the Philippines. 10 students performed the drama excerpt, they were identified by the subject teacher using the fishbowl technique.

\section{Collection of Data}

The researcher prepares the drama excerpt on Romeo and Juliet identified the respondent by using the fishbowl technique to get a sample size of grade 7 . The English subject teacher requested the student to performed drama excerpts and using rubrics to get the speaking ability of the respondent. 


\section{Data Analysis}

A scoring rubric will be used in this test to prevent bias assessment. The writer used the analytic one. Barkaoui (2011) exposed that analytic scoring might be more appropriately called analytic assessment to capture its closer association with classroom language instruction than with formal testing. Since the test is oral, therefore there is only an instruction. It can be concluded that the suitable scoring rubric for this study is the analytic one. The subject English teacher facilitated the scoring of the drama excerpt using rubrics.

Table 1. Scoring Rubric for Drama Excerpt

\begin{tabular}{|c|c|c|c|c|}
\hline \multirow[t]{2}{*}{ Criteria } & \multicolumn{4}{|c|}{ Points } \\
\hline & 4 & 3 & 2 & 1 \\
\hline $\begin{array}{l}\text { Body } \\
\text { Language }\end{array}$ & $\begin{array}{l}\text { Movements seemed fluid } \\
\text { and helped the audience } \\
\text { visualize }\end{array}$ & $\begin{array}{l}\text { Made } \\
\text { movements or } \\
\text { gestures that } \\
\text { enhanced } \\
\text { articulation. }\end{array}$ & $\begin{array}{l}\text { Very little } \\
\text { movement or } \\
\text { descriptive } \\
\text { gestures }\end{array}$ & $\begin{array}{l}\text { No movement } \\
\text { or descriptive } \\
\text { gestures }\end{array}$ \\
\hline Eye contact & $\begin{array}{l}\text { Holds the attention of } \\
\text { the entire audience with } \\
\text { the use of direct eye } \\
\text { contact }\end{array}$ & $\begin{array}{l}\text { Consistent use of } \\
\text { direct eye } \\
\text { contact with the } \\
\text { audience }\end{array}$ & $\begin{array}{l}\text { Displayed } \\
\text { minimal eye } \\
\text { contact with } \\
\text { the audience }\end{array}$ & $\begin{array}{l}\text { No eye } \\
\text { contact with } \\
\text { the audience }\end{array}$ \\
\hline $\begin{array}{l}\text { Introduction } \\
\text { and closure }\end{array}$ & $\begin{array}{l}\text { The student delivers } \\
\text { open and closing } \\
\text { remarks that capture the } \\
\text { attention of the audience } \\
\text { and set the mood }\end{array}$ & $\begin{array}{l}\text { Student display } \\
\text { clear } \\
\text { introductory or } \\
\text { closing remarks }\end{array}$ & $\begin{array}{l}\text { The student } \\
\text { uses either an } \\
\text { introductory } \\
\text { or closing } \\
\text { remark, but } \\
\text { not both }\end{array}$ & $\begin{array}{l}\text { The student } \\
\text { does not } \\
\text { display clear } \\
\text { introductory } \\
\text { or closing } \\
\text { remarks. }\end{array}$ \\
\hline Pacing & $\begin{array}{l}\text { Good use of drama and } \\
\text { student meets } \\
\text { apportioned time } \\
\text { interval }\end{array}$ & $\begin{array}{l}\text { Delivery is } \\
\text { patterned but } \\
\text { does not meet } \\
\text { apportioned } \\
\text { time interval }\end{array}$ & $\begin{array}{l}\text { Delivery is in } \\
\text { bursts and } \\
\text { does not meet } \\
\text { apportioned } \\
\text { time interval }\end{array}$ & $\begin{array}{l}\text { Delivery is } \\
\text { either too } \\
\text { quick or too } \\
\text { slow to meet } \\
\text { apportioned } \\
\text { time interval }\end{array}$ \\
\hline Poise & $\begin{array}{l}\text { Students display a } \\
\text { relaxed, self-confident } \\
\text { nature about self, with } \\
\text { no mistakes. }\end{array}$ & $\begin{array}{l}\text { Makes minors } \\
\text { mistakes, but } \\
\text { quickly recovers } \\
\text { from them; } \\
\text { display }\end{array}$ & $\begin{array}{l}\text { Displays mild } \\
\text { tension; has } \\
\text { trouble } \\
\text { recovering } \\
\text { from mistakes }\end{array}$ & $\begin{array}{l}\text { Tension and } \\
\text { nervousness } \\
\text { is obvious; } \\
\text { has trouble } \\
\text { recovering } \\
\text { from mistakes }\end{array}$ \\
\hline Voice & $\begin{array}{l}\text { The use of fluid speech } \\
\text { and inflection maintains } \\
\text { the interest of the } \\
\text { audience. }\end{array}$ & $\begin{array}{l}\text { Satisfactory use } \\
\text { of inflection, but } \\
\text { does not } \\
\text { consistently use } \\
\text { fluid speech }\end{array}$ & $\begin{array}{l}\text { Display some } \\
\text { level of } \\
\text { inflection } \\
\text { throughout } \\
\text { the delivery }\end{array}$ & $\begin{array}{l}\text { Consistently } \\
\text { uses a } \\
\text { monotone } \\
\text { voice }\end{array}$ \\
\hline
\end{tabular}

Table 2.Classifying the score of students by using the following scale

\begin{tabular}{cc}
\hline Scale & Classification \\
\hline $3.25-4.0$ & Excellent \\
$2.52-3.27$ & Very Good \\
$1.76-2.51$ & Good \\
$1.00-1.75$ & Fair \\
\hline
\end{tabular}




\section{Statistical Tool}

The following tools were used in the study:

Weighted Mean: The weighted mean is used quantify the result prior and after the exposure on drama excerpt

$$
\mathrm{WM}=\frac{T W F}{N}
$$

Where WM is weighted mean, $\mathrm{F}$ is frequency of the number of responses, $\mathrm{W}$ is weight of the category of responses, and $\mathrm{N}$ is number of responses. Five-Point Rating Scale. The Likert-type scale was used in quantifying and interpreting the weighted mean for each indicator, consisting of the following interpretation.

Table 3. Interpretations of Scale

\begin{tabular}{cl}
\hline Scale & Verbal Interpretations \\
\hline 5 & Excellent \\
4 & Very Good \\
3 & Good \\
2 & Fairly Good \\
1 & Not Good \\
\hline
\end{tabular}

\section{RESULT AND DISCUSSION}

\section{Result}

This chapter presents data collected by analysis, interpretation, and conclusions related to the problems raised in this study, in junior high school at the University of Saint Anthony through. Drama excerpt is a tool in enhancing the speaking ability of the based on body language, eye contact, introduction and closure, pacing, poise, voice.

Table 4. The Speaking Ability of the Student before the Exposure Using Drama Excerpt

\begin{tabular}{lcc}
\hline \multicolumn{1}{c}{ Criteria } & Weighted Mean & Verbal Interpretation \\
\hline \hline Body Language & 2.0 & Good \\
Eye Contact & 2.8 & Very Good \\
Introduction and Closure & 2.8 & Very Good \\
Pacing & 2.8 & Very Good \\
Poise & 2.6 & Very Good \\
Voice & 3.5 & Excellent \\
\hline \hline Average Weighted Mean & 2.75 & Very good \\
\hline
\end{tabular}

Shown in Table 4 the Speaking Ability of the student before the exposure Using Drama Excerpt of Romeo and Juliet. The on body language has a weighted mean (WM) 2.0 and verbal interpretation good on eye contact has weighted mean (WM) 2.8 and verbal interpretation very good on Introduction and closure has weighted mean (WM) 2.8 and verbal interpretation very good on pacing has weighted mean (WM) 2.8 and verbal interpretation very good on poise has weighted mean (WM) 2.6 and verbal interpretation very good on the voice has weighted mean (WM) 3.5 and verbal interpretation excellent.

It implies that the highest data before the exposure result on the speaking ability of the student using drama excerpt of Romeo and Juliet is from the criteria of voice used of fluid speech and inflection maintains the interest of the audience, students are more confident with what they are speaking because students are more familiar with the use of English and the medium of instruction used in the Junior High School student in English. 
Further, the speaking ability of the student using drama excerpts is on poise. Minor's mistakes, but quickly recovers from them display, students make mistakes in speaking is natural but students immediately improve in drama conversations about Romeo and Juliet. Making mistakes in speaking English often occurs for everyone, especially in the practice of English drama.

The average weighted mean on speaking ability of the student before the exposure result of using drama excerpt with a weighted mean (WM) of 2.75 with a verbal interpretation of good. From the results junior high school students at the University of Saint Anthony spoke English, they had good pronunciation but for their body language, they were still embarrassed, because the teacher had not explained the rules for evaluating drama practice confident about her body language and students only talk without any intonation.

Based on table 5 the student after the exposure result in the speaking ability of the student in drama excerpt in Romeo and Juliet. The criteria on body language have a weighted mean (WM) 2.9 and verbal interpretation of good criteria on eye contact has weighted mean (WM) 3.3 and verbal interpretation of very good criteria on introduction and closure has weighted mean (WM) 3.1 and verbal interpretation very good while criteria on pacing has weighted mean (WM) 3.9 and verbal interpretation very good criteria on poise has weighted mean (WM) 3.8 and verbal interpretation very good criteria on Voice has weighted mean (WM) 3.9 and verbal interpretation excellent. The average weighted mean (AWM) is 3.45 with the verbal interpretation of excellent. It implies.

From the results the junior high school students at the University of Saint Anthony easily understand what the teacher had explained especially the junior high school students in the Philippines had spoken English every day, they speak English both in the classroom and outside the classroom and the teacher here they almost explained all the lessons using English in the classroom so they were used to hearing and speaking English so they immediately understood what the teacher had explained.

Table 5. The Speaking Ability of the Student after the Exposure Using Drama Excerpt

\begin{tabular}{lcl}
\hline \multicolumn{1}{c}{ Criteria } & Weighted Mean & Verbal Interpretation \\
\hline \hline Body Language & 2.9 & Good \\
Eye Contact & 3.3 & Very Good \\
Introduction and Closure & 3.1 & Very Good \\
Pacing & 3.9 & Very Good \\
Poise & 3.8 & Very Good \\
Voice & 3.9 & Excellent \\
\hline Average Weighted Mean & 3.45 & Excellent \\
\hline
\end{tabular}

The result implies that there were increases in the weighted mean of all criteria in portraying the drama excerpt. This is because of the Student after the Exposure Using Drama Excerpt use by the subject teacher explaining the proper and correct way of presenting using criteria on body language. Students who have practiced on the use of good drama students can meet predetermined time intervals because in the story or drama there are provisions of time and students have fulfilled it in the practice of drama Romeo and Juliet and students are accustomed to using fluent speech because in the Philippines the language English is a second language so they are accustomed to speaking English, especially they are junior high school students at the University of Saint Anthony. 
As shown in table 6 the improvement observed to the students after the exposure on drama excerpt shows a significant increase in all indicators.

Table 6. Improvements Observed to the students after the exposure on Drama Excerpt

\begin{tabular}{cccc}
\hline Indicator & $\begin{array}{c}\text { Weighted Mean } \\
\text { Before Exposure }\end{array}$ & $\begin{array}{c}\text { Weighted after } \\
\text { the exposure }\end{array}$ & $\begin{array}{c}\text { Verbal } \\
\text { interpretation }\end{array}$ \\
\hline \hline Body language & 2.0 & 2.9 & Increase \\
Eye contact & 2.8 & 3.3 & Increase \\
Introduction and & 2.8 & 3.1 & Increase \\
closure & & & \\
Pacing & 2.8 & 3.9 & Increase \\
Poise & 2.6 & 3.8 & Increase \\
Voice & 3.5 & 3.9 & Increase \\
\hline Average & 2.75 & 3.45 & Increase \\
\hline
\end{tabular}

This implies that treatment on the correct and proper way is dramatization was conducted by the English teacher that enhancer the speaking ability of the students to speak and perform the dialogue from the excerpt of Romeo and Juliet. The result further knows that speaking the English language in the Philippines is not difficult because it is the medium of instruction in all levels of education.

\section{Discussion}

Asserts, role-play or drama are used for having fun and motivating, quiet students have the opportunity to express themselves toward progress, the environment in the classroom and outside class becomes infinite, and offers opportunities for the use of language widely (CJ, 2018). Real situations can be created and whatever mistakes they make don't overburden them.

Nihal (2010) further stated that role-play or drama is one of all communication methods that can develop students fluently in language, which promotes interaction in the classroom, and which increases motivation. Roleplay or drama also not only encourages students to learn with their peers but also increase the togetherness of teachers and students to be responsible for the learning process. Roleplay or drama is perhaps the most flexible method and teachers who immediately use role-play or drama can meet unlimited needs with effective and appropriate role-play training.

This research focused on the implementation of educational drama techniques in improving students' speaking accuracy and fluency. The research was conducted in two cycles and each cycle was done in three meetings. The result of the research showed that the students' improvement from the first to the second cycle was improved highly. It was proved by the students' success obtained by the students through the test of Before the Exposure, cycle 1 and cycle 2, where the students' success in speaking ability test in the Before the Exposure It is evidenced by the success of the students obtained by the students through the Exposure of the Student After the Exposure Using Higher Drama Excerpt with Average 3.45 and Before the success of the students obtained by the students through The Speaking Ability of the Student smaller to Average 2.75 .

Based on the finding of the research, the researcher concluded that the educational drama technique improves the third-year students' accuracy and fluency in speaking significantly. Because the research was successful, the writer suggests the teacher uses educational drama techniques to teach speaking. It can make the students' interest and have good confidence when 
they want to speak. In line with this, through the dramatics activities, students not only gain an understanding of grammatical structure in a context but also experiences the dynamics and productive use of the language to influence, control, entertain, and inform, that is, as if in real communicative circumstances (Sapuan et al., 2012).

This material contains oral communication activities to help students achieve confidence and become effective speakers to many types of communications challenges both formal and informal gatherings(Romano, 1994). Each activity is designed to help participants better understand some facet of communications and gain expertise and proficiency in communication(Hanna Sundari \& Dasmo, 2014).

Thus, the activities will make participants think about communication in new and different ways than they ever did before. They will also find these exercises not only useful but also memorable. Each is time tested and ageless. Have fun presenting these activities along with the students.

\section{CONCLUSION AND ADVICE}

Based from the findings of the study, the following conclusions were drawn: the result of indicates that the respondents were able to perform the conversation in the drama excerpt because English is the medium of instruction in the Philippines; the result is higher, due to the interventions of a treatment given by the subject teacher on the correct and proper way of delivery is a dialogue on drama excerpt; and there is a significant improvement observed to the students after the exposure to drama excerpt. Furthermore, these are the recommendations of this paper: dramatization should be made as a teaching strategy to improve the speaking ability of the students; activities on speaking English should be conducted regularly in all subject course to achieve mastery and effective in oral communication, and the oral communication guide for speaking English should be used that will help students acquire better knowledge and understanding on oral communications.

\section{ACKNOWLEDGEMENT}

The authors gratefully acknowledge the financial support from Universitas Ahmad Dahlan, Indonesia, and we would like to thank the reviewers for their comments on this article.

\section{REFERENCES}

Apriyanto, S., \& Anum, A. (2018). Gender Dynamics on Speaking Interaction in the College Classroom. Jurnal Smart, 4(2), 73. https://doi.org/10.26638/js.692.203x

Ariyanti, A. (2016). Psychological Factors Affecting EFL Students' Speaking Performance. ASIAN TEFL Journal of Language Teaching and Applied Linguistics, 1(1), 77-88. https://doi.org/10.21462/asiantefl.v1i1.14

Barbee, M. (2010). Drama as Pedagogy in L2 Learning : A Literature Review. Language, Culture, Literature, 2(1), 1-25.

Barkaoui, K. (2011). Think-aloud protocols in research on essay rating: An empirical study of their

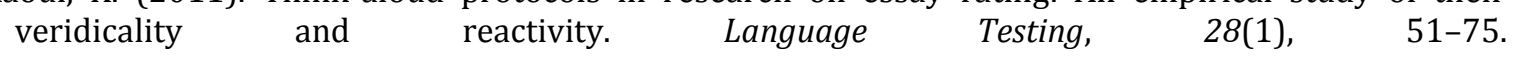
https://doi.org/10.1177/0265532210376379

CJ, J. (2018). Improving the Students Speaking Ability Through Role Play Method. IJET (Indonesian Journal of English Teaching), 7(1), 87-97. https://doi.org/10.15642/ijet2.2018.7.1.87-97

Elliott, R., \& Timulak, L. (2015). Descriptive and interpretive approaches to qualitative research. In J. M. and P. Gilbert (Ed.), A Handbook of Research Methods for Clinical and Health Psychology (pp. 147157). Oxford University Press. https://doi.org/10.1093/med:psych/9780198527565.001.0001

Febriyanti, E. R. (2011). Teaching speaking of English as a foreign language: problems and solutions. Jurnal Bahasa, Sastra, Dan Pembelajarannya., 1(2), 133-146.

Hanna Sundari, \& Dasmo. (2014). the Effect of Speaking Self-Efficacy and Gender in Speaking Activities. 
$\begin{array}{llllll}\text { Bahasa Dan } & \text { Sastra, } & \text { 14, } & \text { No. } & \text { 2(2), }\end{array}$ http://ejournal.upi.edu/index.php/BS_JPBSP/article/view/719/519

Janudom, R., \& Wasanasomsithi, P. (2009). Drama and Questioning Techniques: Powerful Tools for the Enhancement of Students' Speaking Abilities and Positive Attitudes towards EFL Learning. Journal of $\begin{array}{lllll}\text { Chemical Information } \quad \text { and } & \text { Modeling, } & \text { (26) }), & \text { 19. }\end{array}$ https://doi.org/10.1017/CB09781107415324.004

Miles, M., Huberman, M., \& Saldana, J. (2014). Qualitative Data Analysis (H. Salmon (ed.); 3rd ed.). SAGE Publication. https://doi.org/10.1080/0140528790010406

Natarova, T. (2011). Intercultural communication experiences of foreign students with a focus on their perspectives of national, cultural and ethnic identity: Case of Exchange and Degree Students in Jyväskylä, $\quad$ Finland. Master's Thesis. https://jyx.jyu.fi/dspace/bitstream/handle/123456789/37101/URN:NBN:fi:jyu2011121811816.pdf?sequence $=1$

Nihal. (2010). Using Drama in Teaching English for Young Learners. SELÇUK ÜNIVERSİTESİ.

Nugroho, R. A. (2018). The Implementation of Teaching-Learning Cycle in English for Hotels Training: A Case Study. ASIAN TEFL Journal of Language Teaching and Applied Linguistics, 3(2), 119-129. https://doi.org/10.21462/asiantefl.v3i2.63

Radic-Bojanic, B., \& Topalov, J. (2016). Textbooks in the EFL classroom: Defining, assessing and analyzing. Collection of Papers of The Faculty of Philosophy XLVI, 3, 137-153. https://doi.org/10.5937/zrffp4612094

Romano, R. (1994). Gender Issues in Teaching: Does Nurturing Academic Success in Women Mean Rethinking Some of What We Do in the Classroom? Speaking of Teaching-Stanford University Newsletter $\quad$..., 6(1), 1-6. http://scholar.google.ch/scholar?hl=en\&q=Gender+Issues+in+Teaching:+Does+Nurturing+Academi $\mathrm{c}+$ Success+in+Women+Mean+Rethinking+Some+of+What+We+Do+in+the+Classroom?\&btnG=\&as sdt=1,5\&as_sdtp=\#0

Sapuan, N., Rahayu, A., \& Rosnija, E. (2012). Teaching English Speaking Fluency By Using Drama. Jurnal Pendidikan Dan Pembelajaran Untan, 1(1), 1-15.

Silverman, D. (2013). Doing Qualitative Research (Katie Metzler (ed.); Fourth Edi). SAGE Publication. https://doi.org/10.1007/s13398-014-0173-7.2

Spielmann, G., \& Radnofsky, M. L. (2001). Learning language under tension: New directions from a qualitative study. Modern Language Journal, 85(2), 259-278. https://doi.org/10.1111/00267902.00108

Umar. (2018). Students ' Speaking Motivation In Learning. Premise: Journal of English Education and Applied Linguistics, 7(1), 57-67. https://doi.org/doi.org/10.24127/pj.v7i2.

Widiati, U., \& Cahyono, B. Y. (2006). The Teaching of EFL Speaking In the Indonesian Context: The State of the Art. Bahasa Dan Seni, 34(2), 269-292. https://doi.org/10.15639/TEFLINJOURNAL.V19I1/1-17 